\title{
PATIENTS WITH TAKAYASU'S ARTERITIS EXHIBIT AN IMPAIRED HEALTH STATUS AND PHYSICAL FUNCTION: A MULTICENTER CROSS- SECTIONAL STUDY
}

Alexandre Moura Dos Santos ${ }^{1, *}$, Rafael Giovani Misse ${ }^{1}$, Isabela Bruna Pires Borges ${ }^{1}$, Alexandre Wagner Silva de Souza ${ }^{2}$, Rosa Maria R Pereira ${ }^{1}$, Samuel Katsuyuki Shinjo ${ }^{1}$

1. Universidade de São Paulo, Faculdade de Medicina, São Paulo (SP). 2. Universidade Federal de São Paulo, São Paulo (SP).

*Corresponding author: alexandrestos@usp.br

\section{BACKGROUND}

Takayasu's arteritis (TAK) is a rare form of primary systemic vasculitis that can lead to general health status impairment. The present study is aimed at assessing TAK patients' health status using various tools focused on the ability to perform activities of daily living (APADL), quality of life (QoL), the ability of walk, and level of physical activity.

\section{MATERIALS AND METHODS}

This multicenter cross-sectional study was conducted from 2019 to 2020. Twenty consecutive female patients with TAK (American College of Rheumatology, 1990) and 16 individuals without TAK (control group, CTR) whose age, gender, and body mass index (BMI) were matched to those of the TAK patients were enrolled in the study. The APADL and QoL were assessed using the Health Assessment Questionnaire (HAQ)1, and Short-Form Health Survey (SF-36)2, respectively, whereas the ability to walk and level of physical activity were assessed using the Walking Impairment Questionnaire (WIQ)3, and International Physical Activity Questionnaire - Short Form (IPAQ-SF)4. Disease activity was measured using the Indian Takayasu Clinical Activity Score (ITAS2010) and The National Institutes of Health (NIH).

\section{RESULTS}

The TAK patients' median age was 41.5 (38.0-46.3) years, and the median BMI was $28.3(26.0-29.7) \mathrm{kg} / \mathrm{m}^{2}$. Three (15\%) TAK patients had disease activity. Eleven used immunosuppressive drugs, and two used also glucocorticoids. The TAK patients exhibited a significant impairment in ADAPL and most subscale domains (Fig.1). Moreover, they also had a significant reduction in WIQ and IPAQ-SF scores, in that 60\% had a low level of physical activity, and none had a high level. The QoL, ADAPL, and IPAQ-SF results did not correlate with disease activity.
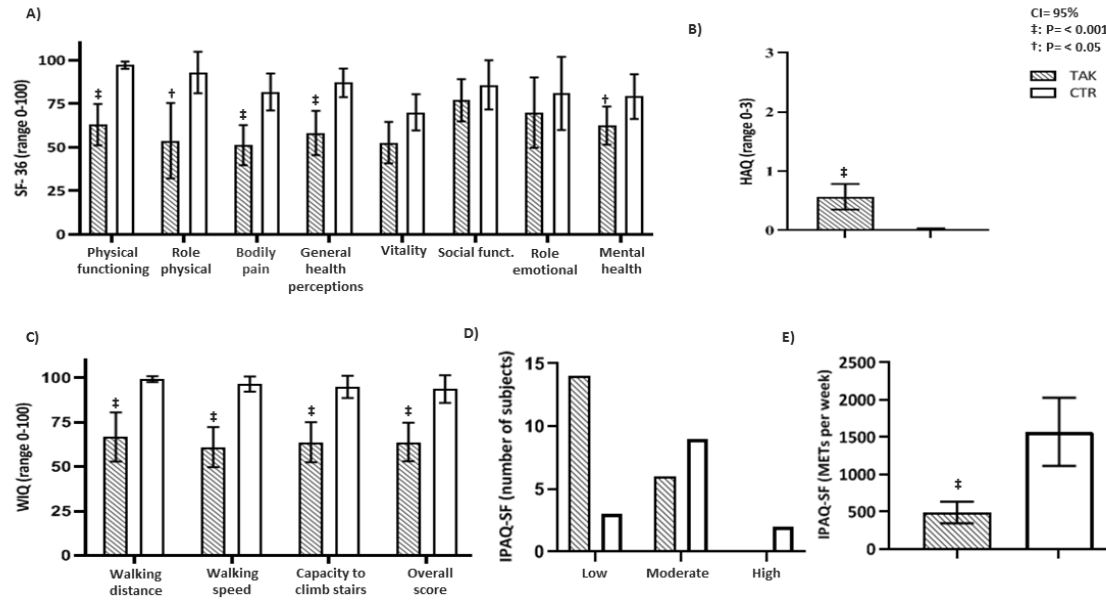

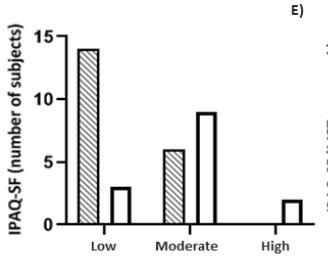

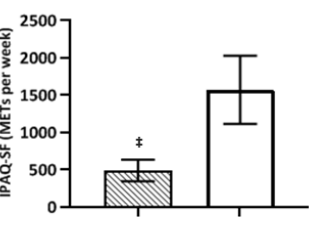

Figure 1. Ability to perform activities of daily living, quality of life and physical activity (METs) of patients Takayasu's arteritis patients and the control group. 


\section{CONCLUSION}

Patients with TAK exhibit global impairment of health status and physical function. Therefore, in addition to conventional drug treatments, it is important to assess TAK patients in all domains, including health status and physical function.

\section{FUNDING}

Fundação de Amparo à Pesquisa do Estado de São Paulo (FAPESP No. 2018/08735-3 to AMS; 2019/12155-5 to RGM; 2019/11367-9 to IBPB; 2019/11776-6 to SKS).

\section{REFERENCES}

1. Ekdahl C, Eberhardt K, Andersson SI, Svensson B. Assessing disability in patients with rheumatoid arthritis: Use of a Swedish version of the Stanford Health Assessment Questionnaire. Scand J Rheumatol. 1988;17(4):263-71. https://doi.org/10.3109/03009748809098795

2. Falcão DM, Ciconelli RM, Ferraz MB. Translation and cultural adaptation of quality of life questionnaires: an evaluation of methodology. J Rheumatol. 2003;30(2):379-85.

3. Ritti-Dias RM, Gobbo LA, Cucato GG, Wolosker N, Jacob Filho W, Santarém JM, etal. Translation and validation of the walking impairment questionnaire in Brazilian subjects with intermittent claudication. Arq Bras Cardiol. 2009;92(2):136-42. https://doi.org/10.1590/S0066-782X2009000200011

4. Matsudo S, Araújo T, Matsudo V, Andrade D, Andrade E, Oliveira LC, et al. Questionário Internacional de Atividade Física (IPAQ): estudo de validade e reprodutibilidade no Brasil. Rev Bras Ativ Fís Saúde. 2001;6:5-18. 